\title{
Banks Credit, Macroeconomic Dynamics and the Performance of Small and Medium Scale Enterprises in Nigeria: A Non-Linear ARDL Approach
}

\author{
Peter E. Ayunku and Gamaliel O. Eweke
}

\begin{abstract}
This paper examines the impact of banks credit and macroeconomic dynamics on Small and Medium Scale Enterprises in Nigeria using annual data from 1992 - 2016. The long-run and short-run relationship amongst the variables were examined via the non-linear ARDL model. The Augmented Dickey Fuller (ADF) and Philip Perron's (PP) test reveals that none of the variables were $I(2)$. The Bounds test to cointegration confirms the existence of a long-run relationship. The non-linear ARDL results suggests that in both long and short-run estimations, that a rise in banks credit, government tax revenue and negative shocks in interest rate, inflation rate and exchange rate will trigger a fall in SMEs performance in Nigeria. Furthermore, it was observed that negative shocks tend to be larger in magnitude than positive ones. This study therefore recommends amongst others, that loans to the small and medium enterprises (SMEs) sector be monitored properly, so as to ensure that such loans are not channelled to other purposes.
\end{abstract}

Index Terms - Banks Credit, Macroeconomic Dynamics, Non-linear ARDL, Small and Medium Enterprises.

\section{INTRODUCTION}

The Small and Medium Scale Enterprises (SMEs) has been adjudged globally as been pivotal to economic growth and development. SMEs can be adjudged to be non-subsidiary and autonomous firms with very few employees, however the number differs across countries. According to the European Union (EU), SMEs are firms with an employee base lesser than 250 persons and an annual turnover not exceeding 50millon euros. In the United States, any firm with an employee base of 500 workers and less is regarded as a small scale enterprise (Stoner, Freeman \& Gilbert, 1996). In India, a firm with a staff strength of 1 to 100 persons, is considered a small scale enterprise. For Uganda, any business unit employing less than 10 persons are micro enterprise, while those with a staff base oscillating between 50 to 100 persons are regarded as medium scale enterprises. In Nigeria, the Central Bank of Nigeria in its monetary circular No 22 of 1998 sees SMEs as businesses having an annual turnover not exceeding 500,000 naira. Furthermore, the National Policy on Micro, Small and Medium Scale Enterprise (MSMEs) in Nigeria defines MSMEs as businesses with a staff strength lesser than 200 persons and

Published on January 5, 2020

Peter E. Ayunku, Niger Delta University, Nigeria (e-mail: peterayunku@yahoo.com).

Gamaliel O. Eweke, Federal University Otuoke, Nigeria (e-mail: apache664@gmail.com). an asset base (excluding land and buildings) not exceeding 500 million naira.

According to the International Council for Small Business (ICSB); Micro, Small and Medium-sized Enterprises (MSMEs) consists of over $90 \%$ of all firms, while accounting for an average of $60-70 \%$ of the total employment and $50 \%$ of the Gross Domestic Product (GDP) of any economy. An investigation carried out by Small and Medium Enterprise Development Agency of Nigeria (SMEDAN) and the National Bureau of Statistics (NBS) in 2013 indicated that the total number MSMEs in the country were $37,067,416$ firms with a nominal contribution to GDP at $48.47 \%$, while accounting for about $7.27 \%$ of the total export.

Unfortunately given this statistics, the growth of the SME sector in the country like many other developing nations is been challenged by a myriad of financial and macroeconomic constraints over the years. Given the fact that SMEs thrives and operates in a dynamic environment subject to various macroeconomic fluctuations (interest rate, exchange rate, money supply, taxes, etc.) its performance are thereby dependent on its interactions with the environment. Progressing from this belief that firms are an integral part of their environment, it is therefore a desideratum that SMEs learn to appreciate and fully understand its environment so as to quickly react to changes which may cause a shift in its performance and productive capacity.

Apart from the introduction, the paper is organised as follows; section two discussed the problem statement, while section three emphasised on the review of literature, section four the econometric procedure, section five discussed the results and findings and in section six conclusions and recommendations are presented.

\section{Problem Statement}

Arguably one of the biggest economies in Africa, Nigeria continues to rely and thrive on her vast oil wealth. In a bid to diversifying the economic base of the nation emphasis have placed on Small and Medium Scale Enterprises (SMEs). This is however not new as programmes and institutions aimed at developing the SME's sector began as far back in the early 1970's. These include the establishment of Bank of Industry (BOI), Small and Medium Enterprises Development Agency of Nigeria (SMEDAN), World Bank Small and Medium Enterprises I Loan, World Bank Small and Medium Enterprises II Loan, Micro-Finance Initiative (MFI), Nigeria Industrial Development Bank (NIDB), Small Scale Industries Credit Scheme (SSICS) and Small and 
Medium Enterprises Equity Investment Scheme (SMEEIS), etc.

Despite concerted effort by the government to improve the performance of SMEs, the potentials of SMEs in Nigeria have not been fully exploited. The major reason adduced for this dismal performance could be traced to poor access to credit facilities. Typically, SMEs are susceptible to a higher transaction costs than larger firms in obtaining credit, as loans to SMEs for capital investment must be long-term in order to avoid a fatal mismatch between project gestation and loan maturity. Consequently, the cost of funds (interest rate) becomes a deciding factor as it significantly impacts on the survival and competitiveness of these SMEs. However, a major concern is that the banking system which is a major source of short-term funds are not providing enough support to the expansion of SMEs, owing to perceived risks associated with SME sector. The long-term source of funds which is the capital market remains quite unreachable for all SMEs in the country at present.

While finance is obviously not the only problem militating against the development of SMEs in the country, macroeconomic fundamentals such as exchange rate depreciation, high monetary policy rate, inflation, taxation, inconsistency in government policies, infrastructural decay, etc. also serves as factors militating against the potentials of SMEs in Nigeria.

\section{LITERATURE REVIEW}

\section{THEORETICAL REVIEW}

This study is guided by a few theories on small and medium enterprises development and banks' lending behaviour.

\section{A. Keynesian Economic Theory}

The main thrust of this theory as postulated by Keynes (1936), rest on the fact that SMEs are vital in the economic development of any country. The theory lends credence to the fact that the activities of SMEs thrives, when the government creates an enabling and conducive environment. This environment thus created must ensure market regulation, efficient resource allocation and stabilization of policies on those macroeconomic fundamentals (inflation rate, exchange rate, interest rate, etc.) that are embedded in the environment affecting the activities of SMEs. Keynes believes that SMEs operate in a dynamic environment subject to several uncertainties and as such SMEs will only thrive in a conducive environment. However, given these uncertainties and dynamism in the business environment, the ability for SMEs to understand its nature becomes crucial as it enables them to be proactive in decision making given an ever changing business environment.

\section{B. Schumpeter Theory of Innovation}

This theory as proposed by Schumpeter (1934) is premised on the fact that entrepreneurs been risk-takers, their innovations are determined based on their pro-activeness to their environment. However, the environment been susceptible to changes overtime, plays a crucial role in their performance as businesses. Moreover, given that such factors domiciled in the environment are external to businesses, an understanding of such factors becomes a sine qua non for efficient decision making, ultimately leading to an improved performance of businesses. Furthermore, Schumpeter sees entrepreneurs as agents of change, individuals creating chaos by unsettling the status quo, developing new products, ideals and driving the market forward. This theory contends that creativity and innovativeness are the fons et origo of entrepreneurship, which further defines business performance.

\section{Loan Pricing Theory}

This theory posits that in trying to adjust the lending rate, banks affect the pricing factors of such loans, which however affects the cost of funds available for lending. This ripple effect triggers the loan uptake by borrowers, which ultimately affect the lending capacity of the banks. According to Stiglitz and Weiss (1981), banks should take into cognizance adverse selection problems moral hazards issues when maximising interest income, due to high information asymmetry available in the credit market. As such if lending rates are too high, this may likely trigger adverse selection in the market, as only risk lovers would take up such loans. Once such loans are received, the borrowers may develop moral hazard behaviour, as they are likely to take-up investments with a high level of risk to compensate for the lending rate (Chodecai, 2004).

\section{Signalling Argument}

This theory argues that a viable company should provide as much collateral as possible so as to signal to banks that they are less risky borrowers. This is in turn would cause the banks to charge a lower interest rate on loans. However, the reverse signal arguments contends that banks only require more collateral for more risky firms' that requires payment of higher interest rates (Chodecai, 2004; Ewert and Schenk 1998).

\section{E. Credit Market Theory}

This theory ties the interest rate required on loans with the bank's income earned from lending activities. It postulates that there exist credit terms that clears the market. In assuming than loans and advances remains constant, the interest rate then becomes the price (credit term) that clears the market. However, a rise in loan demand given a certain customer base level will spike a surge in interest rate, vice versa. Ewert, Szczesmy \& Schenk (2000) contends that a rise in the default risk by borrowers will necessitate an increase in the interest premium to cover against any occurring losses arising from default in the future. The main thrust of this theory rest on two major factors; bank's income and interest rate. A higher interest rate means more income for banks, but a rise in interest rate makes borrowers prone to default risk. Consequently any rate above the optimal interest rate may lead to possible losses and less income for banks.

\section{EMPIRICAL REVIEW}

Erdogan (2018) inquired into the factors affecting SMEs access to bank financing in Turkey, using semi-structured interviews conducted with 25 Turkish bank managers and 
thematic analysis. The findings concluded that commitment of SMEs to its credit obligations, age of the firm, relationship with the bank, industry which the firm operates and limited financial data affects its access to bank loans. Bodgan, Marek, George et. al (2018) investigated the impact of credit availability on SMEs in Poland using a panel logistic regression. Their findings showed that small and medium firms have more limited access to credit than large companies.

Ubesie, Onuaguluchi and Mbah (2017) examined the effect of deposit money banks on SME growth in Nigeria from 1986-2015 within the OLS framework. Their findings indicated that banks credit has no significant effect on SME growth, while interest rate were found to exert a negative and significant effect on SME growth. Orogbu, Onyeizugbe and Chukwuma (2017) using the OLS method explored the implications of the economic environment on SMEs and economic growth in Nigeria from 1970-2016. The authors observed that inflation rate, government tax, exchange rate and interest rate exerted a negative effect on SMEs performance.

Duru, Yusuf and Kwazu (2017) studied the role of microfinance banks credit on SMEs development in Lokoja, Kogi State in Nigeria using descriptive and chi-square statistic. The findings indicated that microfinance banks credit have positively impacted on the expansion capacity of SMEs in the region. Oaya and Mambula (2017) using descriptive statistics and Pearson product moment correlation assessed the impact of SMEs financing on business growth in Nigeria. Their findings indicated access to finance as been key to entrepreneurial development, while interest charged on loans and advances do not hinder SMEs ability to borrow. Oke and Aluko (2015) explored the impact of commercial banks on SME financing in Nigeria from 2002-2012. Using panel data regression, their findings indicated banks credit to SMEs explained a substantial portion of changes affecting SME financing.

Bassey, Asinya and Amba (2014) examined the behaviour of bank lending and macroeconomic policies on SMEs growth in Nigeria exploring data from 1992-2011. Using the Ordinary Least Square (OLS) regression technique, their findings revealed a significant and positive relationship between bank credits and the growth of SMEs in Nigeria. Imoughele and Ismaila (2014) within the vector error correction model investigated the impact of commercial banks credit on SMEs in Nigeria, from 1986-2012. Their findings suggested that banks credit have an insignificant impact on SMEs output. Onakoya, Fasanya, and Abdulrahman, (2013) applying the OLS technique, studied the impact of loans to SMEs in Nigeria from 1986 to 2014. Their findings suggested that credits exerted a negative effect on SMEs growth in the country.

From the studies above, we found that the result as to the true nature of banks credit on SMEs performance in Nigeria were either varying or inconclusive, as previous studies assumed the relationship between banks credit on SMEs performance to be linear. Hence this study as an attempt to examine the effect of banks credit and macroeconomic dynamics on SMEs performance in Nigeria using a nonlinear approach.

\section{ECONOMETRIC PROCEDURE}

\section{NON-LINEAR AUTOREGRESSIVE DISTRIBUTED LAG (ARDL)}

Most relationship existing among macroeconomic variables tend to be non-linear in nature as opposed to a linear one. This however suggests that the results obtained from a linear analytical technique may be inappropriate in drawing strong inference (Shin, Yu and Greenwood, 2011). This study follows the non-linear ARDL (NARDL) technique as proposed by Shin, Yu and Greenwood (2011) derived from the expansion of the linear ARDL proposed by Pesaran, Shin and Smith (2001). This non-linear ARDL methodology uses positive and negative partial sum decomposition, allowing for the detection of asymmetric effects in both the long and short-run.

This NARDL technique also retains the advantages of the traditional linear ARDL/bounds test as propounded by Pesaran and Shin (1999); Pesaran, Shin and Smith (2001) which performs better in small samples and can be applied irrespective of the integration order, i.e. I(0) and I(1). Secondly, the non-linear ARDL framework by Shin et al. (2011) also allows for the detection of hidden cointegration. According to Granger and Yoon (2002), two time series are said to have hidden cointegration if their positive and negative components are cointegrated.

Given our variables of interest, we thus specify our model;

\section{Equation 1}

$S M E P F_{t}=\beta_{o}+\beta_{1} \ln B C_{t}+\beta_{2} I N T R_{t}+\beta_{3} E X C H R_{t}+\beta_{4} I N F R_{t}$ $+\beta_{5} \ln G T R_{t}+e_{t}$

Where $\ln$ is natural logarithm, BC is banks credit to SMEs, INTR is the prevailing interest rate, EXCHR is exchange rate, INFR is inflation rate and GTR is government tax revenue.

Given the linear specification in equation (1), it would not be possible to capture the asymmetric impact of the independent variables on SMEs performance. Hence in accounting for asymmetries in our study, we re-specify our model as follows;

\section{Equation 2}

$$
\begin{aligned}
\text {SMEPF }_{t}=\lambda_{0}+ & \lambda_{1} \ln B C_{t}+\lambda_{2} I N T R_{t}^{+}+\lambda_{3} I N T R_{t}^{-} \\
& +\lambda_{4} E X C H R_{t}^{+}+\lambda_{5} E X C H R_{t}^{-}+\lambda_{6} I N F R_{t}^{+} \\
& +\lambda_{7} I N F R_{t}^{-}+\lambda_{8} \operatorname{lnGTR}_{t}+e_{t}
\end{aligned}
$$

Where $\lambda_{i}$ is a vector of the long-run coefficients. The asymmetric impact of interest rate, exchange rate and inflation rate is accounted for by including positive changes $I N T R_{t}^{+} \quad E X C H R_{t}^{+} I N F R_{t}^{+}$and negative changes $I N T R_{t}^{-}$ $E X C H R_{t}^{-} I N F R_{t}^{-}$. Where;

$I N T R_{t}^{+}$and $I N T R_{t}^{-}=$partial sums of the positive and negative changes in $I N T R_{t}$

$\mathrm{EXCHR}_{t}^{+}$and $E X C H R_{t}^{-}=$partial sums of the positive and negative changes in $E X C H R_{t}$

$I N F R_{t}^{+}$and $I N F R_{t}^{-}=$partial sums of the positive and negative changes in $I N F R_{t}$

However, given a series $\phi$, positive and negative changes in $\phi_{\mathrm{t}}$ can be derived thus; 


\section{Equation 3}

$$
\text { Positive }=\phi_{t}^{+}=\sum_{i=1}^{t} \Delta \phi_{t}^{+}=\sum_{i=1}^{t} \max \left(\phi_{i}, 0\right)
$$

and

$$
\text { Negative }=\phi_{t}^{-}=\sum_{i=1}^{t} \Delta \phi_{t}^{-}=\sum_{i=1}^{t} \min \left(\phi_{i}, 0\right)
$$

The non-linear ARDL form, can be written from equation (2) as;

\section{Equation 4}

$$
\begin{aligned}
\Delta S M E P F_{t}=\lambda_{0}+ & \lambda_{1} \ln B C_{t-1}+\lambda_{2} I N T R_{t}^{+}+\lambda_{3} I N T R_{t}^{-} \\
& +\lambda_{4} E X C H R_{t}^{+}+\lambda_{5} E X C H R_{t}^{-}+\lambda_{6} I N F R_{t}^{+} \\
& +\lambda_{7} I N F R_{t}^{-}+\lambda_{8} \ln G T R_{t} \\
& +\sum_{j=1}^{n} \varphi_{1} \Delta S M E P F_{t-1}+\sum_{j=1}^{n} \sigma_{2} \Delta \ln B C_{t-1} \\
& +\sum_{j=1}^{n} \tau_{3} \Delta I N T R_{t-1}^{+}+\sum_{j=1}^{n} \underline{\omega}_{4} \Delta I N T R_{t-1}^{-} \\
& +\sum_{j=1}^{n} \rho_{5} \Delta E X C H R_{t-1}^{+}+\sum_{j=1}^{n} \dot{c}_{6} \Delta E X C H R_{t-1}^{-} \\
& +\sum_{j=1}^{n} \ddot{v}_{7} \Delta I N F R_{t-1}^{+}+\sum_{j=1}^{n} V_{8} \Delta I N F R_{t-1}^{-} \\
& +\sum_{j=1}^{n} \pi_{9} \Delta G T R_{t-1}+v_{t}
\end{aligned}
$$

In applying the non-linear ARDL approach, this paper follows the general to specific procedure as used in Katrakilidis and Trachanas (2012). First, we conducted a unit root test to ascertain the integration order of our variables, to confirm that none of our variables are stationary at second difference. The second step is to generate positive and negative series for our desired variables.

Next we test for cointegration using the bounds test of Pesaran et.al (2001) and Shin et.al (2011) among the variables, for linear and non-linear specifications in equation (1) and (2) respectively in an unrestricted error correction model as in equation (4). This is done using the F-test, where the null hypothesis of no cointegration, $\lambda_{1}=\lambda_{2}=\lambda_{3}=\lambda_{4}=\lambda_{5}=\lambda_{6}=\lambda_{7}=\lambda_{8}=0$ is tested against the alternate hypothesis of cointegration, $\lambda_{1} \neq \lambda_{2} \neq \lambda_{3} \neq \lambda_{4} \neq \lambda_{5} \neq \lambda_{6}$ $\neq \lambda_{7} \neq \lambda_{8} \neq 0$. Next we further confirm the presence of asymmetries using the Wald test, even after using the bounds test. We then proceed to run the Non-Linear ARDL using the stepwise regression.

\section{DATA SOURCES}

This study used annual time series data for the period 1992 2016, sourced from Central Bank of Nigeria (CBN) statistical bulletin and National Bureau of Statistics.

\section{RESUlTS AND DisCUSSION OF FINDINGS}

\section{UNIT RoOT TEST}

To ensure that none of the variables are integrated of order, I(2) and to avoid spurious results. The Augmented Dickey Fuller (ADF) and Phillip Perron (PP) test were used to access the integrated order of the variables. As show in Table 1 below, we established that none of the variables were $\mathrm{I}(2)$, as they were either I(1) or I(0).

Table 1 Unit Root Test Results

\begin{tabular}{llccc}
\hline Variables & ADF Test & Remarks & PP Test & Remarks \\
\hline SMEPF & $-7.542872 * *$ & $\mathrm{I}(1)$ & $-8.661885 * * *$ & $\mathrm{I}(1)$ \\
\hline $\operatorname{lnBC}$ & $-3.876495 * * *$ & $\mathrm{I}(0)$ & $-3.973483 * * *$ & $\mathrm{I}(0)$ \\
\hline INTR & $-5.240489 * * *$ & $\mathrm{I}(0)$ & $-5.832359 * * *$ & $\mathrm{I}(0)$ \\
\hline EXCHR & $-3.158938 * *$ & $\mathrm{I}(1)$ & $-3.164092 * *$ & $\mathrm{I}(1)$ \\
\hline INFR & $-4.649968 * * *$ & $\mathrm{I}(1)$ & $-4.653587 * * *$ & $\mathrm{I}(1)$ \\
\hline $\operatorname{lnGTR}$ & $-6.094361 * * *$ & $\mathrm{I}(1)$ & $-6.348628 * * *$ & $\mathrm{I}(1)$
\end{tabular}

$* / * * / * * *$, indicates significance at $1 \%, 5 \% \& 10 \%$ respectively.

Test includes Trend and Intercept

Source: Authors Computation Using Eviews 10+.

\section{BOUNDS TEST FOR LINEAR (ARDL) AND NON-LINEAR (NARDL) COINTEGRATION}

According to Table 2, the F-statistic for the linear ARDL model with a value of 3.427 suggests the absence of cointegration. However the F-statistic of the non-linear model with a value of 6.752 exceeds both the lower and upper critical bounds, suggesting the presence of a long-run relationship.

Table 2 Bounds Test

\begin{tabular}{lcrrr}
\hline \hline & & & & \\
$\begin{array}{l}\text { Model } \\
\text { Specification }\end{array}$ & $\begin{array}{c}\text { F- } \\
\text { statistic }\end{array}$ & $\begin{array}{r}\text { lower } \\
\text { bound }\end{array}$ & $\begin{array}{c}\text { upper } \\
\text { bound }\end{array}$ & Conclusion \\
\hline \hline & & & & \\
Linear & 3.427 & 4.267 & 5.473 & No Cointegration \\
Non-linear & 6.752 & 3.710 & 5.018 & Cointegration \\
\hline \hline
\end{tabular}

Note: the critical values are from Narayan (2004) case III 5\% significance level. The optimal lag order is based on AIC

Source: Authors Computation Using Eviews 10+

\section{NON-LINEAR ARDL LONG \& SHORT-RUN EsTIMATES}

From table 3 below, we find out that all the variables in the long and short-run model have a negative impact on SMEs performance (SMEPF) except positive shocks of interest rate (INTR_POS), inflation rate (INFR_POS) and exchange rate (EXCHR_POS). Our model indicates that a rise in banks credit $(\mathrm{BC})$ in both the long and short-run model would lead to a significant fall in SMEPF. Also an increase in government tax revenue is also likely to trigger a fall in SMEPF, although not statistically significant.

Furthermore bad news (negative shocks in interest rate, inflation rate and exchange rate) would lead to a fall in SMEPF, vice versa. We also noticed that in the short-run negative shocks in inflation rate (INFR_NEG) is significant at $1 \%$, with a negative impact of $13.7 \overline{2} \%$, as opposed to a 
insigificant relationship with a negative impact of $0.13 \%$ in the long-run. This however suggests that inflation is more likely to have more significant effect on SMEPF in the short-run as against the long-run.

From our model (long and short-run), we observed that SMEPF reacted more to bad news (negative shocks in interest rate, inflation rate and exchange rate) as opposed to good news (positive shocks in interest rate, inflation rate and exchange rate). This can be seen in the magnitude of the coefficients of both positive and negative shocks of each variable.

Table 3 Nonlinear ARDL Estimation Dependent Variable: SMEPF

\begin{tabular}{|c|c|c|c|c|}
\hline \multicolumn{5}{|c|}{ Long-run Estimation } \\
\hline Variable & Coefficient & Std. Error & t-Statistic & Prob. \\
\hline $\operatorname{lnBC}$ & -0.428401 & 0.111574 & -3.839602 & $0.0121^{\mathrm{a}}$ \\
\hline INTR_POS & 0.233183 & 0.117849 & 1.978665 & $0.1008^{\mathrm{c}}$ \\
\hline INTR_NEG & -0.257483 & 0.101336 & 2.540887 & $0.0518^{\mathrm{b}}$ \\
\hline INFR_POS & 0.039428 & 0.032514 & 1.212627 & 0.2794 \\
\hline INFR_NEG & -0.052982 & 0.761717 & -0.761717 & 0.5003 \\
\hline EXCHR_POS & 0.026805 & 0.007339 & -3.652150 & $0.0147^{\mathrm{a}}$ \\
\hline EXCHR_NEG & -0.037672 & 0.047794 & 0.788222 & 0.4663 \\
\hline $\operatorname{lnGTR}$ & $-4.11 \mathrm{E}-08$ & $5.68 \mathrm{E}-08$ & -0.724176 & 0.5014 \\
\hline $\mathrm{C}$ & -4.465439 & 2.690118 & -1.659942 & 0.1578 \\
\hline \multicolumn{5}{|c|}{ Short-run Estimation } \\
\hline $\mathrm{SMEPF}_{\mathrm{t}-1}$ & -1.891584 & 0.322667 & -5.862341 & $0.0020^{\mathrm{a}}$ \\
\hline $\operatorname{lnBC} C_{t-1}$ & -0.810356 & 0.267972 & -3.024031 & $0.0293^{\mathrm{b}}$ \\
\hline INTR_POS $_{\mathrm{t}-1}$ & 0.441086 & 0.222279 & 1.984381 & $0.1040^{\mathrm{c}}$ \\
\hline INTR_NEG $\mathrm{t}_{\mathrm{t}-1}$ & -0.487052 & 0.209239 & 2.327728 & $0.0674^{\mathrm{c}}$ \\
\hline DINFR_POS ${ }_{\mathrm{t}-1}$ & 0.074581 & 0.063115 & 1.181673 & 0.2905 \\
\hline DINFR_NEG $\mathrm{t}_{\mathrm{t}-1}$ & -0.137279 & 0.012971 & -10.58327 & $0.0001^{\mathrm{a}}$ \\
\hline DEXCHR_POS ${ }_{\mathrm{t}-1}$ & 0.050704 & 0.016193 & -3.131125 & $0.0259^{\mathrm{b}}$ \\
\hline DEXCHR_NEG ${ }_{t-1}$ & -0.071260 & 0.092913 & 0.766951 & 0.4777 \\
\hline DlnGTRt-1 & $-7.77 \mathrm{E}-08$ & $1.04 \mathrm{E}-07$ & -0.745574 & 0.4895 \\
\hline
\end{tabular}

Diagnostic Tests

\begin{tabular}{llll}
\hline \hline R-squared & 0.883808 & Durbin -Watson Stat. 2.689627 \\
Adj R-squared & 0.784302 & Normality (Jarque-Bera) 0.919569 \\
S.E Regression & 0.235184 & Serial Correlation & 1.206517 \\
F-Statistic & 924.6430 & Heteroskedascity & 0.003446 \\
Prob(F-Statistic) & 0.000000 & & \\
\hline \hline
\end{tabular}

$\mathrm{a} / \mathrm{b} / \mathrm{c}$, indicates significance at $1 \%, 5 \%$ \& $10 \%$ respectively.

Source: Authors Computation Using Eviews 10+

From table 3 above, the result as presented in the later part of the model suggests that the model cleared all diagnostic tests such as serial correlation, normality and heteroskedascity. Furthermore, the coefficient stability of the non-linear ARDL model was accessed via the CUSUM and CUSUMQ recursive residual test. The estimated coefficients of the model are deemed to be stable over the study period, if the plots are within the 5\% critical bounds as shown in Appendix 2.

\section{LONG-RUN AND SHORT-RUN ASYMMETRY}

The Wald test was used to access the variables for the presence of asymmetry in both the long-run and short-run. From table 4, the findings indicated that the null hypothesis of no asymmetry can be rejected. Hence, we accept that positive and negative effect of the independent variables in the long-run and short-run are not equal.

Table 4 Wald Test Statistic for Long-run and Short-run Asymmetry

\begin{tabular}{|c|c|c|c|c|}
\hline \multirow[b]{2}{*}{ Variables } & \multicolumn{2}{|c|}{ Long-run Asymmetry } & \multicolumn{2}{|c|}{ Short-run Asymmetry } \\
\hline & t-statistic & $\begin{array}{l}\text { Probability } \\
\text { value }\end{array}$ & t-statistic & $\begin{array}{l}\text { Probability } \\
\text { value }\end{array}$ \\
\hline $\ln B C$ & -1.231403 & 0.2729 & -0.712937 & 0.4850 \\
\hline INTR & -1.690401 & 0.1517 & -1.346088 & 0.1950 \\
\hline EXCHR & -1.271539 & 0.2207 & -0.043438 & 0.9658 \\
\hline INFR & -1.490184 & 0.1827 & -1.622725 & 0.1220 \\
\hline $\operatorname{lnGTR}$ & -0.670105 & 0.5113 & -1.331578 & 0.1988 \\
\hline Source: $\mathrm{Au}$ & Computat & Using Evie & & \\
\hline
\end{tabular}

This study examined the impact of banks credit and macroeconomic dynamics on Small and Medium Scale Enterprises in Nigeria using annual data spanning 1992 2016. The long-run and short-run estimations were accessed via the non-linear ARDL model developed by Shin et.al (2011). The Augumented Dickey Fuller and Philip-Perron unit root tests indicated that none of the variables were integrated of order two, I(2). Furthermore, the bounds test supported the existence of a stable and long-run relationship amongst the variables.

The findings of the study indicated that in both long and short-run estimations, that a rise in banks credit (BC), government tax revenue (GTR) and negative shocks in interest rate, inflation rate and exchange rate (INTR NEG, INFR_NEG and EXCHR_NEG) will trigger a fall in SMEs performance in Nigeria. We therefore share the views of Akpan and Eweke (2018) who stated that government should put in motion policies that will trigger aggressive rural banking, while lowering the interest rate and by extension single digit inflation rate in the economy. Furthermore, we recommend amongst others that;

1. Loans to the small and medium enterprises (SMEs) sector be monitored properly, so as to ensure that such loans are not channeled to other purposes, other than the reason be applied for.

2. The government should adequately address issues relating to multiple taxation on small and medium enterprises and by extension even grant tax holidays. As such may likely increase their purchasing power and help the grow sector.

3. A guided deregulation mechanism of the foreign exchange market similar to that adopted during the Abacha administration should be adopted by the government. As this will help maintain the value of the 
naira and in turn enhance the value of credits available to improve SMEs investments.

4. In other to enhance proper utilization of funds granted to SMEs and also improve the ease of doing business; economic and social infrastructure in terms of electricity supply and good transportation network be improved by the government.

5. Training scheme should be provided by Money Deposit Banks to help train SMEs in financial best practices. As this well help improve transparency, record-keeping and accountability for enhanced performance.

\section{APPENDIX}

\section{1: Descriptive StATISTICS}

\begin{tabular}{lcccccc}
\hline & SMEPF & $\begin{array}{c}\text { LOG } \\
(\mathrm{BC})\end{array}$ & INTR & INFR & EXCHR & $\begin{array}{c}\text { LOG } \\
(\mathrm{GTR})\end{array}$ \\
\hline Mean & 1.01800 & 0.52896 & 11.7728 & 19.8340 & 108.7089 & 14.7209 \\
\hline Median & 1.01000 & 1.28093 & 11.1200 & 12.9000 & 125.8331 & 15.1817 \\
\hline Max & 2.47000 & 3.29583 & 28.0200 & 72.8000 & 253.4923 & 16.4849 \\
\hline Min & -0.0700 & -2.3025 & 1.5000 & 5.4000 & 17.2984 & 12.1571 \\
\hline Std. Dev. & 0.7632 & 2.1503 & 4.8819 & 18.1491 & 63.6132 & 1.4678 \\
\hline Skew & 0.2400 & -0.2747 & 1.3432 & 1.7841 & -0.0686 & -0.4781 \\
\hline Kurt & 1.7743 & 1.3626 & 6.7270 & 4.9328 & 2.4630 & 1.8612 \\
\hline & & & & & & \\
\hline J.B & 1.8048 & 3.1073 & 21.987 & 17.1547 & 0.3199 & 2.3032 \\
\hline Prob & 0.4056 & 0.2114 & 0.00001 & 0.000188 & 0.8521 & 0.3161 \\
\hline & & & & & & \\
\hline Sum & 25.450 & 13.2240 & 294.320 & 495.8500 & 2717.722 & 368.023 \\
\hline Sum Sq. & 13.9828 & 110.972 & 572.001 & 7905.426 & 97119.38 & 51.7074 \\
\hline & & & & & &
\end{tabular}

$\begin{array}{lllllll}\text { Obs } & 25 & 25 & 25 & 25 & 25 & 25\end{array}$

Source: Authors Computation Using Eviews 10+

\section{2: Plot of Cumulative Sum and Cumulative Sum of SQuARES OF RECURSIVE RESIDUALS STABILITY TESTS}

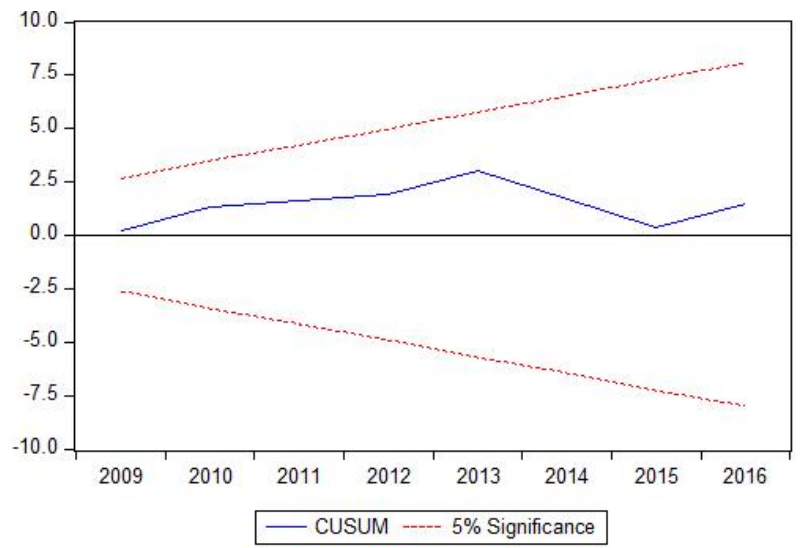

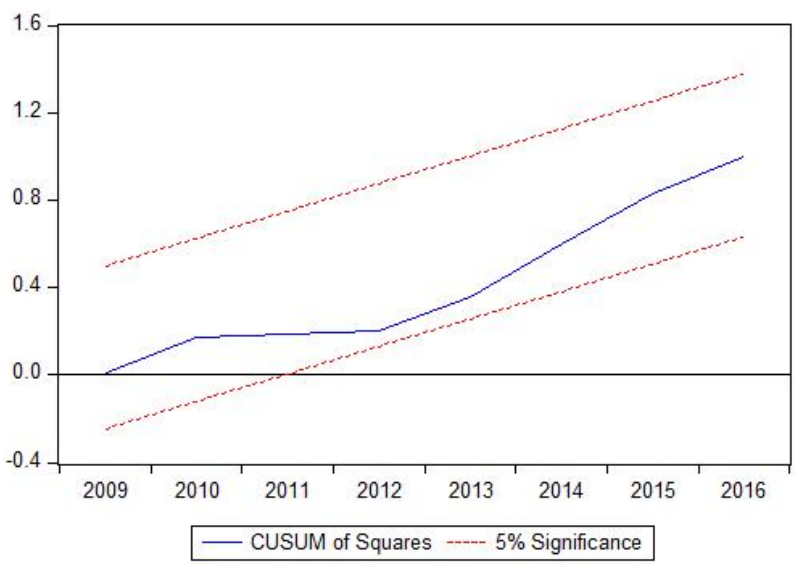

3: NoRmality TESt: JARQUE-Bera StATISTICS

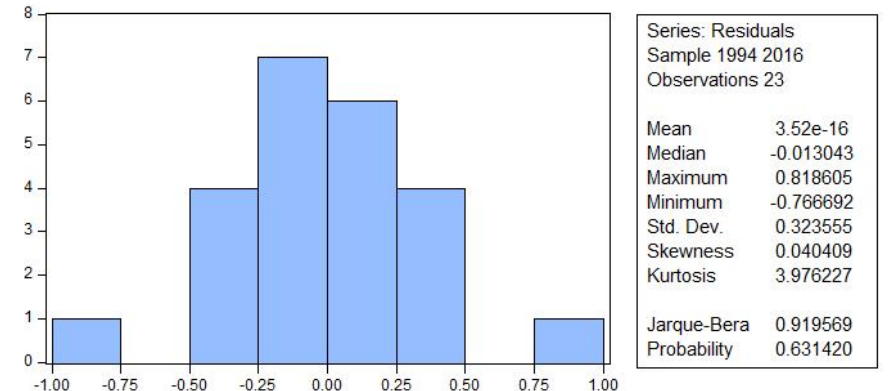
Source: Authors Computation Using Eviews 10+

\section{4: Heteroskedasticity Test: ARCH:}

\begin{tabular}{lcll}
\hline \hline F-statistic & 0.003446 & Prob. F $(1,20)$ & 0.9538 \\
Obs*R-squared & 0.003790 & Prob. Chi-Square(1) & 0.9509 \\
\hline \hline \multicolumn{4}{c}{ Source: Authors Computation Using Eviews 10+ }
\end{tabular}

\section{5: Breusch-Godfrey Serial Correlation LM} TEST:

\begin{tabular}{lclc}
\hline \hline & & & \\
F-statistic & 1.206517 & Prob. F(5,12) & 0.3633 \\
Obs*R-squared & 8.028911 & Prob. Chi-Square(1) & 0.1546
\end{tabular}

Source: Authors Computation Using Eviews 10+

\section{REFERENCES}

Akpan, E.S and Eweke, G.O. (2018). Banks Credit and Manufacturing Sector Performance in Nigeria: A Comparison of Autoregressive Distributed Lag (ARDL) and Vector Error Correction Model (VECM) Approach. Journal of International Finance and Economics, 18(3), 47-64

Bassey, N. E, Asinya, F.A. and Amba, E.A. (2014). Bank Lending Macro Policy Variables and the Growth of Small and Medium Scale Enterprises in Nigeria. International Journal of Business and Social Science, 5(9), 5-6.

Bogdan, W., Marek, S., George, I., Daniela F. and Ramona, P. (2018). The Impact of Credit Availability on Small and Medium 
Companies. Entrepreneurship and Sustainability Issues, 5(3), 565 -580 .

Dada, R. M. (2014). Commercial Banks' Credit and SMEs Development in Nigeria: An Empirical Review. International Journal of Research, 1(8): 305-319.

Duru, I.U., Yusuf, A. and Kwazu, V.C (2017). Role of Microfinance Banks Credit in the Development of Small and Medium Enterprises in Lokoja, Kogi State, Nigeria. Asian Journal of Economics, Business and Accounting, 5(3), 1-9.

Erdogan, A.I. (2018). Factors affecting SME Access to Bank Financing: An Interview Study with Turkish Bankers. Small Enterprise Research, 25(1), 23-35.

Imoughele, L.E. and Ismaila, M. (2014). The Impact of Commercial Bank Credit on the Growth of Small and Medium Scale Enterprises: An Econometric Evidence from Nigeria (1986 - 2012) Empirical Evidence from Nigeria. Journal of Educational Policy and Entrepreneurial Research (JEPER), 1(2), 251-261.

Katrakilidis C and Trachanas E. (2012). What drives housing price dynamics in Greece: New Evidence from Asymmetric ARDL Cointegration Econ Model 29:1064-1072.

Oaya, C.T. and Mambula, J.C (2017). The Impact of SMEs Financing on Business Growth in Nigeria: A Study of Keffi and Mararaba Metropolis. International Journal of Innovation and Economic Development, 3(2), $44-55$.

Oke, M.O. and Aluko, O.A. (2015). Impact of Commercial Banks on Small and Medium Enterprise Financing In Nigeria. IOSR Journal of Business and Management (IOSR-JBM), 17(4), 23-26.

Onakoya, A. B. O., Fasanya, I. O. and Abdulrahman, H. D. (2013). The Effect of Loan to Small and Medium Scale Enterprises Entrepreneurs. European Journal of Business and Management, 5(4), 130-136.

Orogbu, L., Onyeizugbe, C.U. and Chukwuma, E. (2017). Economic Environment of Small and Medium Scale Enterprises: Implications on Economic Growth in Nigeria. Journal of Economics, Management and Trade. 19(4): 1-12.

Stoner, J. A. F., Freeman, R. E., and Gilbert D. R. (1996) Management. New Delhi: Prentice Hall.

Ubesie, M.C, Onuaguluchi, I.F. and Mbah, A.M. (2017). Effect of Deposit Money Banks Credit on Small and Medium Scale Enterprises Growth in Nigeria. International Journal of Finance and Accounting, 6(5), 117-132.

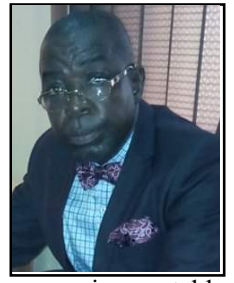

Peter E. Ayunku, MAMN, FCFIP, holds a $\mathrm{PhD}$ degree in Banking and Finance from Ebonyi State University, Nigeria. He is currently an Associate Professor of Finance; Dean, Faulty of Management Science, Niger Delta University and also a member of, the Academy of Management Nigeria and Fellow Forensic Investigation Professional, USA.

He has published several local and international papers in reputable journals and also attended both local and international conferences. Further, he has successfully supervised over 15 postgraduate students at both PGD, MSc and PhD levels. He is currently an external examiner to the Department of Finance and Banking, University of PortHarcourt. His research interest are Finance, Bank Management, Emerging Capital Markets, Investment Analysis and Portfolio Management and Financial Econometrics.

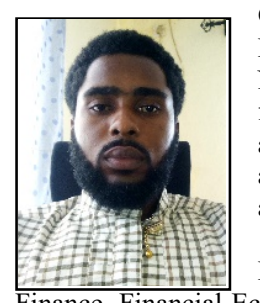

Gamaliel O. Eweke, holds a Masters degree in Finance and Banking from Niger Delta University, Nigeria and a Bachelors degree in Accounting from Federal Unversity Otuoke, Nigeria. He is also a Freelance Data Analyst with over 10 academic paper publications in reputable local and international journals.

His research interests cuts across; International Economics, Applied Macroeconomic Modelling and Forecasting, Corporate Finance, Financial Accounting and Capital Markets. 